\title{
Transformations in Statehood, the Investor- State Regime, and the New Constitutionalism
}

\author{
A. Claire Cutler \\ University of Victoria, ccutler@uvic.ca
}

Follow this and additional works at: https://www.repository.law.indiana.edu/ijgls

Part of the Human Rights Law Commons, Insurance Law Commons, International Trade Law Commons, and the Law and Economics Commons

\section{Recommended Citation}

Cutler, A. Claire (2016) "Transformations in Statehood, the Investor- State Regime, and the New Constitutionalism," Indiana Journal of Global Legal Studies: Vol. 23 : Iss. 1 , Article 5.

Available at: https://www.repository.law.indiana.edu/ijgls/vol23/iss1/5

This Article is brought to you for free and open access by the Law School Journals at Digital Repository @ Maurer Law. It has been accepted for inclusion in Indiana Journal of Global Legal Studies by an authorized editor of Digital Repository@Maurer Law. For more information, please contactrvaughan@indiana.edu.

\section{$\Psi$}

JEROME HALL LAW LIBRARY

INDIANA UNIVERSITY

Maurer School of Law
Bloomington 


\title{
Transformations in Statehood, the Investor- State Regime, and the New Constitutionalism
}

\author{
A. Claire CUTLeR*
}

\begin{abstract}
This paper examines the changing boundaries of statehood resulting from transformations in the nature and operation of public and private authority over local and global politico-legal orders. Transformations in the political purposes of states are being driven by powerful elites who advance a new form of constitutional governance. New constitutionalism, as evidenced by the investor-state regime, subordinates the interests, purposes, and rights of national citizens to those of foreign, transnational politico-legal, and economic elites. This regime is a highly privatized order that is expanding in influence, both in terms of the commercial activities under its remit, and in terms of its procedural operation and its normative influence. The specific focus of this paper is on the investor-state regime, which is contributing to the expansion of private power and authority in the settlement of investment disputes. This regime is effecting two transformations in the scope and nature of statehood. One transformation involves the imposition of severe limits upon the legislative and policy autonomy of national governments that are being developed and enforced by private commercial actors without public accountability. In agreeing to protect the private property rights of foreign investors against legislation or public policy that might impair foreign investment, states are also limited in their abilities to ensure the protection of the social, economic, or human rights of their peoples. However, this expansion of private power and authority is generating a countermovement in the form of resistance to the regime. This resistance is giving rise to a conflicting transformation in statehood as national governments seek to regain their policy and legislative autonomy. In some cases, the impetus comes from local sources, while in others it emanates from global and international human rights fora. This paper
\end{abstract}

* Professor of International Relations and International Law, Department of Political Science, University of Victoria, Victoria, British Columbia, Canada; MSc (LSE); PhD (UBC); LLB (McGill).

Indiana Journal of Global Legal Studies Vol. 23 \#1 (Winter 2016)

(C) Indiana University Maurer School of Law 
begins with an overview of the operational nature of the investor-state regime and new constitutionalism, revealing how the procedural and substantive provisions of the regime reach deep inside states to set clear limits on their legislative and policy autonomy. It then examines a selection of cases before investor-state tribunals that reveal contestation and resistance to the regime through the reassertion by state governments of their sovereignty and through the influence of international human rights. It concludes with an exploration of the potential for this regime to advance human rights protections and suggests a few changes that might enhance the regime's democratic legitimacy.

\section{INTRODUCTION}

As a student of the political foundations of international economic law, it is easy to be pessimistic about the possibility of humanizing capital's law-the law facilitating the mobility and expansion of capitalism. ${ }^{1}$ Such pessimism is rooted in a deep suspicion of the distinctions between public and private international law and between economics and politics that work to depoliticize the entire realm of international commercial and economic activity and legality and to immobilize national political authorities. Liberal mythology concerning the natural, neutral, apolitical, and efficient nature of private international economic law has been eroding societal and democratic controls and facilitating the denationalization and delocalization of capital for some time. These processes of denationalization and delocalization have in turn transformed statehood by severely constraining the legislative and policy autonomy of national governments to pursue public purposes. The potential for international investment contracts and trade agreements to advance human rights appears to be small, if not zero. Indeed, the raison d'être of these contracts and agreements is the advancement and protection of the private property interests of foreign investors. There appears to be very little room for the advancement or protection of national or local public interests-such as social, labor, or environmental rights-in contracts and agreements whose stated purposes are the protection of the private property interests of foreign investment and trading companies.

1. See A. Claire Cutler, Global Capitalism and Liberal Myths: Dispute Settlement in Private International Trade Relations, 24 MILLENNIUM: J. INT'L STUD. 377, 381-87 (1995) (illustrating how economic and political elites have manipulated the boundary between private and public international trade law as a means of insulating international commercial transactions from national and democratic controls). 
However, much has been changing in the governance of the global political economy and its intersection with local political-legal and social orders, effecting further transformations in statehood.2 Many governments find themselves enmeshed in networks of investment and trade commitments that severely restrain their abilities to respond to challenges posed by turbulent world markets, as in the cases of the Argentine and Greek financial crises. Others, like Canada, find themselves responsible for the payment of large sums in damages awards upon arbitral rulings that they breached their investmentprotection commitments to foreign companies. ${ }^{3}$ Indeed, the movement to denationalized and delocalized control over foreign direct investment has generated a countermovement in the form of resistance to the regime. In a manner reminiscent of the double movement characterizing the advent of market civilization theorized by Karl Polanyi, the investor-state regime is generating contestation. ${ }^{4}$ Some states have severely constrained the ambit of investment protections, like Australia, while others have gone so far as to exit the global investment regime, as in the case of many South American states. ${ }^{5}$ Criticisms about the closed, elitist, and nondemocratic nature of dispute settlement under the trade and investment regimes have been increasingly articulated, and states such as Canada and the United States are responding by reasserting their sovereignty in the form of provisions that increase the democratic legitimacy of these regimes.

At the global level, John Ruggie, as the Special Representative of the United Nations Secretary General on Business and Human Rights, initiated a widespread examination of the impact of the foreign investment regime on human rights. This initiative resulted in the

2. See A. Claire Cutler, Morris Tabaksblat Chair on Private Actors and Globalization, Hague Inst. for the Internationalisation of Law (HiiL), BITs: Turning Shields into Swords? (April 23, 2012) (Public Lecture delivered at Leiden University and co-sponsored by HiiL and the Grotius Centre for International Legal Studies for the launch of the Tabaksblat Chair).

3. See generally AbitibiBowater Inc. v. Government of Canada, Consent Award (ICSID Dec. 15, 2010), http:/www.international.gc.ca/trade-agreements-accordscommerciaux/assets/pdfs/disp-diff/abitibi-03.pdf.

4. See generally KarL Polanyi, The Great Transformation: The Political and ECONOMIC ORIGINS OF OUR TIME (1944) (using Polanyi's concept of "double movement" to capture how the transformation or movement from a feudal to market economy generated counter-movements to protect society from the disruptions caused by the operations of unregulated markets).

5. These criticisms of the investor-state regime are outlined in, U.N. CONFERENCE ON Trade AND DeV., World INVESTMENT REPORT 2015, at 125, U.N. Sales No. E.15.II.D.5 (2015), available at http://unctad.org/en/PublicationsLibrary/wir2015_en.pdf [hereinafter WORLD INVESTMENT REPORT], and prompted the characterization of the present time as an "era of re-orientation" to the regime. 
development of United Nations Guiding Principles on Business and Human Rights (UNGPs) that articulate the social responsibilities of investing corporations. ${ }^{6}$ The UNGPs are now part of a broader discussion of Principles for Responsible Investment that are being developed within the United Nations Conference on Trade and Development's (UNCTAD) Investment Policy Framework for Sustainable Development. ${ }^{7}$ At UNCTAD's 2014 and 2015 World Investment Forums, there was significant debate over the nature and operation of the investor-state regime. States including Brazil, India, and Indonesia voiced significant criticism of the private arbitration proceedings that form the core of dispute settlement under the regime. ${ }^{8}$ Other international organizations, such as the United Nations Commission on International Trade Law (UNCITRAL) and the World Bank's International Centre for the Settlement of Investment Disputes (ICSID) are revisiting and revising the rules and procedures governing investment arbitration to address many of these criticisms. ${ }^{9}$

These developments suggest that the terrain of public and private authority over local and global political economies is shifting as local and global movements aspire to gain greater control over the activities of foreign investing corporations and over the actions of their national governments. This paper tells a story about this shifting terrain of statehood, situating dispute settlement under the investor-state regime in the broader context of power and contestation in the governance of the global political economy. Part I examines the broad contours of the investor-state regime, illustrating its origins in the protection of private foreign investment interests and its operation as a form of new

6. The Guiding Principles have been adopted by the United Nations Human Rights Council and form the basis for a U.N. Working Group on Business and Human Rights. See generally JOHN GERARD RUGGIE, JUST BUSINESS: MULTINATIONAL CORPORATIONS AND HUMAN RIGHTS (2013) (providing an account of Ruggie's activities as Special Representative); Larry Catá Backer, Fractured Territories and Abstracted Terrains: Human Rights Governance Regimes Within and Beyond the State, 23 IND. J. GLOBAL LEGAL STUD. 61 (2016) (discussing UNGPs); Hans Lindahl, One Pillar: Legal Authority and a Social License to Operate in a Global Context, 23 IND. J. GLOBAL LEGAL STUD. 201 (2016) (same).

7. See Investment Policy Framework for Sustainable Development Introduction: Introduction, UNCTAD INVESTMENT POLICY HUB, http://investmentpolicyhub.unctad.org/ ipfsd (last visited June 11, 2015) (explaining the guidance for policymakers found in the 2015 Investment Policy Framework for Sustainable Development).

8. See WORLD INVESTMENT REPORT, supra note 5, at 125-132.

9. See generally U.N. Comm'n on Int'l Trade, Rules on Transparency in Investor-State Arbitration (2014), available at http://www.uncitral.org/pdf/english/texts/arbitration/rules on-transparency/Rules-on-Transparency-E.pdf [hereinafter Rules on Transparency]; see also Leon E. Trakman, The ICSID Under Siege, 45 CORNELL INT'L L.J. 603 (2012) (evaluating the criticisms leveled at the ICSID). 
constitutionalism. Part II examines contestation over the regime principles and decisionmaking procedures and examines a few select cases that illustrate how appeals to international human rights are transforming both state authority and the investor-state regime. Part III assesses the potential for the investor-state regime to address perceived defects in its operation and its ability to further respond to human rights challenges in the form of the protection of social, labor, and environmental rights.

\section{The CONTOURS of THE INVESTOR-STATE REgIME}

The investor-state regime forms a key element in the constitution of the material and normative foundations of transnational capitalism. It is also of profound significance to transformations in statehood that are relocating authority between private and public actors in governance. In fact, the investor-state regime continues to expand as more states enter into international investment agreements (IIAs) every year. UNCTAD reports that in 2014 there were twenty-seven new IIAs, bringing the total to $3,268 .^{10}$ At least forty-five states and four regional associations are involved in revising their agreements, ${ }^{11}$ while investors continue to use investor-state dispute settlement proceedings, with cases initiated against developed states rising to about 40 percent of the cases. ${ }^{12}$ Of 356 concluded cases, 37 percent were decided in favor of the state, while 25 percent in favor of the investor. ${ }^{13}$

The regime is so foundational that it is aptly described as a form of "new constitutionalism." New constitutionalism is a political project aimed at the continuous expansion of capitalism through the entrenchment into national and international legal frameworks of neoliberal, market-oriented laws and policies that favor privatization, liberalization, and deregulation of trade, investment, and financial services, and a host of economic, social, and cultural activities. ${ }^{14} \mathrm{New}$ constitutional disciplines of trade and investment activities are evident

10. IIA Team, U.N. Conference on Trade \& Dev., IIA Issues Note, No. 1: Recent Trends in IIAS and ISDS 2 (Feb. 2015), available at http://unctad.org/en/ PublicationsLibrary/webdiaepcb2015d1_en.pdf. Note that these figures do not reflect cases that were withdrawn, settled or conducted in secrecy.

11. Id. at 2 .

12. Id. at 5 .

13. Id. at 8 .

14. See generally NEW CONSTITUTIONALISM AND WORLD ORDER (Stephen Gill \& A. Claire Cutler eds., 2014); A. Claire Cutler, International Commercial Arbitration, Transnational Governance, and the New Constitutionalism, in INTERNATIONAL COMMERCIAL ARBITRATION AND GLOBAL GOVERNANCE: CONTENDING THEORIES AND EVIDENCE 140 (Walter Mattli \& Thomas Dietz eds., 2014). 
in three characteristics of these legal regimes: the significant insulation of foreign investment and trade relations from interference by states; the agreement to standards of behavior that limit the policy and legislative autonomy of states; and the commitment to dispute settlement in private arbitral proceedings subject to no or minimal legal review by national governments and courts.

While the investor-state regime forms part of the larger international investment regime, it concerns investment arrangements between states. Unlike other international commercial investment arrangements involving private, commercial, and corporate actors, the investor-state regime binds the activities of states. It is thus rooted in public international law. This is an important consideration that should become clear as the origins of the investor-state regime are addressed. The investor-state regime basically provides for investment security by protecting foreign investors from the expropriation of their assets without due compensation and from other measures that might impair their investment. The regime also provides for dispute resolution in delocalized settings to avoid potential interference from national policymakers and courts of law. The regime thus removes significant dimensions of the foreign investment relationship from local or national political and legal contestation, control, and review. This "denationalizing" and "delocalizing" of the investment relationship is precisely what the regime is designed to do. Indeed, these purposes originate in the colorful history of the regime and form the basis for its contemporary contestation.

\section{A. Historical Origins of Denationalized/Delocalized Control: Transformation $I$}

Historically, foreign-owned property was governed by reciprocal agreements amongst European trading states of roughly equal bargaining power. Over time, however, these reciprocal relationships gave way to relations of imposition as the rules were applied through colonial and imperial expansion to non-European states. ${ }^{15}$ Putatively "reciprocal" arrangements were replaced increasingly with one-way bargains as powerful capital-exporting states were able to dictate the terms governing the investments of their nationals to less powerful

15. See Kate Miles, The ORigins of International INVESTMENT LaW: EMPIRE, ENVIRONMENT AND THE SAFEGUARDING OF CAPITAL (2013) (providing a fascinating account of the investment regime); ANTONY ANGHIE, IMPERIALISM, SOVEREIGNTY AND THE MAKING OF INTERNATIONAL LAW (2004) (explaining the colonial foundations of international law). 
states who were hosting the investment. ${ }^{16}$ More often than not, disputes over foreign investment were settled by force and "gunboat diplomacy." 17 By the nineteenth century, colonial powers entered into treaties of Friendship, Commerce, and Navigation (FCN treaties). While FCN treaties were not directed specifically at foreign investment, but were rather drafted to encourage international trade, they did offer some protection for the assets of foreigners. As Jeswald Salacuse notes, gradually, greater protections were included in these treaties, although they did not provide for direct dispute resolution by investors against host states. ${ }^{18}$ Foreign investors essentially had two options if their investment was somehow impaired by the host state. As the doctrine governing international legal personality identifies states as the primary subjects of international law and generally does not allow an individual or corporation to take a legal action against a state, foreign investors had to rely on diplomacy and political influence in order to persuade their home state to advance a legal claim on their behalf. ${ }^{19}$ The alternative was to initiate a claim in the national court of the host state under national law. Neither option proved to be satisfactory for the foreign investors; the first did not guarantee compensation, while the second rarely resulted in their success.

After World War II, the United States began incorporating investment protections into its FCN treaties. The United States supported what was known as the "Hull Rule," articulated by U.S. Secretary of State Cordell Hull in a note to the Mexican Minister of Foreign Affairs, concerning compensation due upon the Mexican expropriation of foreign-owned agrarian and oil properties. ${ }^{20}$ The Hull Rule describes the standard of compensation due under customary international law as "adequate, effective and prompt" compensation. ${ }^{21}$ However, while supported by the developed world, this rule was challenged in the post-World War II period by developing countries who were emerging as independent states during decolonization. The wave

16. See Charles Lipson, Standing Guard: Protecting Foreign CaPital in the NINETEENTH AND TWENTIETH CENTURIES 133 (1985) ("LDCs have managed to redefine the rules affecting international investments and so alter the context of bargaining between individual firms and host countries.").

17. Barnali Choudhury, Recapturing Public Power: Is Investment Arbitration's Engagement of the Public Interest Contributing to the Democratic Deficit?, 41 VAND. J. TRANSNAT'L L. 775, 780 (2008).

18. Jeswald W. Salacuse, The Emerging Global Regime for Investment, 51 HARV. INT'L L.J. $427,438,444$ (2010).

19. Id. at 439 .

20. See ANDrew Newcombe \& Lluís Paradell, Law and Practice of Investment TREATIES: STANDARDS OF TREATMENT 18 (2009).

21. Id. 
of nationalizations and expropriations (direct takings) without compensation that took place during this time led to the erosion of the rule as a principle of customary international law. Mexico rejected the rule, as did other Latin American countries and the Soviet Union. ${ }^{22}$ These states engaged in massive expropriations without compensation. Salacuse observes that the average number of nationalizations of foreign investor property rose steadily from about slightly more than fifteen per year in 1960 to over fifty per year in $1975 .{ }^{23}$

During this time the United Nations General Assembly (UNGA) was the focus of developing countries' claims for a New International Economic Order. The 1962 UNGA Resolution on Permanent Sovereignty Over Natural Resources articulated the standard of compensation as appropriate compensation in accord with laws of the host state, ${ }^{24}$ and by the mid-1970s the rule had ceased to have the status of customary international law. This left the law governing foreign investment uncertain, with capital exporting states advancing the Hull Rule, and capital importing states rejecting it in a highly politicized standoff.

International investment agreements emerged as the solution to the uncertainty over the applicable legal rules and standards in the late 1960s, although the first Bilateral Investment Treaty (BIT) was entered into in 1959 between West Germany and Pakistan. Japan and the United States eventually signed BITs as well-Japan in 1977 and the United States in $1982 .{ }^{25}$ The significant thing about these agreements is that they delocalized and denationalized the investment relationship by providing investing corporations and individuals the legal rights to sue the host state directly in binding arbitration proceedings conducted by arbitrators selected by the disputing parties outside the legal institutions of the host state. ${ }^{26}$ The International Centre for the Settlement of Investment Disputes (ICSID) was created in 1966 under the auspices of the World Bank to provide investors with the institutional framework for taking direct legal action under a BIT against host states. ${ }^{27}$ At first the developing countries were unwilling to use it: ICSID heard its first case in $1972 .{ }^{28}$ However, as the UNCTAD

22. See A. Claire Cutler, Human Rights Promotion Through Transnational Investment Regimes: An International Political Economy Approach, 1 Pol. \& Governance 16, 19 (2013).

23. See Salacuse, supra note 18 , at 435 n. 42.

24. See Cutler, supra note 22 , at 19.

25. Andrew T. Guzman, Why LDCs Sign Treaties That Hurt Them: Explaining the Popularity of Bilateral Investment Treaties, 38 VA. J. INT'L L. 639, 653 \& n.54 (1998).

26. Id. at 680 .

27. See Convention on the Settlement of Investment Disputes Between States and Nationals of Other States art. 1, United Nations, Oct. 14, 1966.

28. See generally Holiday Inns/Occidental Petroleum v. Government of Morocco, ICSID Case No. ARB/72/1 (1972). 
World Investment Report 2015 notes, the pace of BIT signing picked up and saw vast expansion by the 1990 s, leading to today's situation where investor-state arbitrations occur regularly under the auspices of ICSID, under Chapter 11 of the North American Free Trade Agreement (NAFTA) and the Energy Charter Treaty.

The development of this investor-state regime and the steady global expansion of international investment agreements are thus due to a number of geopolitical, economic, institutional, and ideological developments. ${ }^{29}$ The important point to note is that these agreements are designed to protect the foreign investor through the guarantee of delocalized and denationalized dispute settlement. In providing direct legal access for foreign investors against host states without having to go to national courts, the agreements bypass the exhaustion of local remedies, a rule commonly applied in a variety of disputes, including those concerning international human rights. Moreover, these agreements in effect grant "private persons and companies the right to compel a sovereign state to appear before a tribunal and defend its sovereign actions ostensibly taken to protect the public interest." 30 This has been described as a "revolutionary innovation" that has caused a "paradigm shift" in and "profound transformation" of international law. ${ }^{31}$ Even in the World Trade Organization (WTO), which possesses one of the most developed dispute settlement systems, private actors do not have legal standing-only states, as members of the WTO, may bring actions. ${ }^{32}$ Salacuse notes of these important developments:

Thus, the global investment regime has granted a private right of action to investors. It has thereby privatized the decisionmaking process to a large extent. Not only are private parties involved as litigants, but also as arbitrators - the decision makers in the processwho are private persons compensated by the disputants,

29. See generally YVes DEZALAY \& BRyant G. GaRTH, Dealing in Virtue: INTERNATIONAL COMMERCIAL ARBITRATION AND THE CONSTRUCTION OF A TRANSNATIONAL LEGAL ORDER (1996) (detailing the construction of an independent legal field that thrust transnational lawyers centrally into international markets).

30. Salacuse, supra note 18 , at 460.

31. Jürgen Bering et al., General Public InTERnATIONAL LAW AND INTERNATional INVESTMENT LAW: A RESEARCH SKETCH ON SELECTED ISSUES 43, 46 \& n.175 (Christian Tietje et al. eds., 2011).

32. Marrakesh Agreement Establishing the World Trade Organization, Apr. 15, 1994, 1867 U.N.T.S. 154. 
not officials of governments or international organizations. ${ }^{33}$

The typical BIT contains three elements: definitions, substantive obligations for host states, and provisions for binding investor-state arbitration. In most treaties, "investment" is defined very broadly to include a range of agreements. Often, "umbrella clauses" are used to bring under the jurisdiction of the BIT all contractual arrangements that the host state might enter into with the foreign investor. This may work to internationalize many contracts that would otherwise be subject to the jurisdiction of the host state's legal system. ${ }^{34}$ In addition to providing definitions of investment, the typical BIT will establish general standards of behavior of the host state. The common standards include "fair and equitable treatment," "full protection and security," "national treatment," "most-favored-nation treatment," and "treatment in accordance with international law." The BIT will also include specific standards concerning the investment, such as dealing with monetary transfers, expropriation, and investor rights during war, revolution, or civil unrest. The BIT will rarely state specific consequences of a breach, but arbitration tribunals have held uniformly that compensation is due upon breaches resulting in injury on the basis of customary international law. Finally, the BIT will provide for a binding enforcement mechanism for investors and will often designate the arbitration institutions and rules to be adopted. Investor-state dispute resolution therefore delocalizes the proceedings by removing them from the jurisdiction of the local legal system. Denationalization and delocalization of controls over foreign investment have in turn generated considerable concern among governments and a variety of civil society groups. Criticism of the regime takes many forms and contributes in significant ways to state transformation.

\section{B. Criticism and the Counter-Movement: Transformation II}

The standard rationale for constitutionalizing investment protections in legal agreements mirrors more general beliefs that the enhanced rule of law is basically good for business. As a lawyer for a leading law firm observes: "It is globally acknowledged that the rule of

33. Salacuse, supra note 18 , at 460 .

34. For a discussion of the transformation in statehood resulting from the internationalization of contracts through the combined forces of private and public international law, see Sheldon Leader, Statehood, Power, and the New Face of Consent, 23 IND. J. GLOBAL LEGAL STUD. 127 (2016). 
law is essential for sustainable long-term economic growth." ${ }^{35}$ According to this view, it is axiomatic that investment protections increase the security of contracts, protect intellectual property rights, and provide for fair dispute resolution, all of which are assumed to contribute to economic development. However, many are questioning whether the investment protections actually do encourage economic development. Several studies reveal that the signing of a BIT has no substantial correlation to an increase in foreign direct investment and that increased investment depends on other factors, such as political climate, resource and transportation availability, and institutional stability. ${ }^{36}$

In addition, the use of investment arbitration to settle disputes has come under attack. It is standard for BITs to provide international arbitration as the method for dispute settlement and to identify the institution to be utilized, such as ICSID or other private arbitration tribunals. Often the arbitration rules to be utilized will also be specified, such as those of the International Chamber of Commerce (ICC) or the United National Commission on International Trade Law (UNCITRAL). NAFTA provides for ICSID or UNCITRAL as the dispute settlement rules available to the parties under the Chapter 11 investor-state provision. ${ }^{37}$

This delocalization of investor-state dispute settlement through binding dispute resolution in specialized tribunals is criticized for locking states into accepting limitations on their legislative and policy autonomy. The "locking in" function is a crucial dimension of the operation of neoliberal discipline under new constitutionalism. ${ }^{38}$ To illustrate, most BITs give general consent to delocalized, binding arbitration. This contrasts with consent that is specific to a particular contract to arbitrate, where the parties will be governed by the domestic rules of contract under the applicable system of private international

35. Kevin Coon, Good Law Means Good Business - in Any Market, ThE GLOBE AND MAIL, June 23, 2015, at B4.

36. See, e.g., Jennifer L. Tobin \& Susan Rose-Ackerman, When BITs Have Some Bite: The Political-Economic Environment for Bilateral Investment Treaties, REv. INT'L ORG. (2006) (showing that BITs cannot be judged in isolation, but instead within the context of political, economic, and institutional features of the host country signing the BIT and in light of the worldwide BITs regime); Jason Webb Yackee, Bilateral Investment Treaties, Credible Commitment, and the Rule of (International) Law: Do BITs Promote Foreign Direct Investment?, 42 LAW \& Soc'Y REV. 805 (2008) (concluding that BITs do not meaningfully influence investment decisions, a result consistent with research).

37. See North American Free Trade Agreement, U.S.-Can.-Mex., Ch. 11, art. 1130, Dec. 17, 1992, 32 I.L.M. 289 (1993).

38. See Stephen Gill, Power and Resistance in the New World Order 163 (2d ed. 2008) ("New constitutionalism can be understood historically as . . a political project to 'lock in' the power gains of capital on a world scale - it combines the old and the radically new."). 
law. The general consent given by a host state in a BIT "is general because it authorizes the arbitration of any future dispute with any foreign investor [of the state party] in the state's territory" and operates like a "blank cheque which may be cashed for an unknown amount at a future, and as yet unknown, date," transforming "investor-state arbitration from a modified form of commercial arbitration into a system to control the state's exercise of regulatory authority with respect to investors as a group." 39

The investor-state regime privatizes dispute settlement by identifying specialized arbitration institutions that operate like a private justice system, quite autonomously from national legal systems. ${ }^{40}$ As mentioned above, NAFTA identifies ICSID and UNCITRAL rules as the dispute settlement mechanisms available to foreign investors. These rules are modeled on the principles governing private commercial arbitration between two parties where confidentiality has been a driving concern. The origins of the investorstate dispute resolution system in the laws and culture of private international commercial arbitration have proved very challenging for democratic forces seeking to gain access to and information about their proceedings. Indeed, in many ways this extension of commercial arbitration to the settlement of disputes involving public authorities is producing a clash of legal cultures between public international law traditions, emphasizing the protection of human rights, the environment, and other matters of public concern, and private international law, emphasizing the autonomy of commercial actors to conduct their private affairs as they see fit.

In fact, many believe that the general consent to delocalized and privatized dispute resolution produces a "democratic deficit":

State parties to investment agreements can no longer legislate at will in the public interest without concern that an arbitral tribunal will determine that the legislation constitutes interference with an investment. Thus investment arbitration may result in an overall loss of state independence and sovereignty, which has

39. Gus Van Harten, Private Authority and Transnational Governance: The Contours of the International System of Investor Protection, 12 REV. INT'L PoL. ECON. 600, 607-08 (2005).

40. See A. Claire Cutler, Private Power and Global Authority: Transnational MERChaNT LAW IN THE GLOBAL POLITICAL ECONOMY 183 (2003) ("The devolution of authority to resolve disputes and to enforce agreements to the private sphere through the increasing legitimacy of private arbitration... [is] perfecting this reconfiguration of political authority. This is reordering state-society relations both locally and globally."). 
implications for democratic governance .... [T] he question arises whether state exercises of public authority should be adjudicated by foreigners, largely on the basis of commercial principles, when the adjudicators are unconcerned with the wider effects of their decisions. ${ }^{41}$

Indeed, some believe that the most significant institutions engaged in investor-state arbitration, such as ICSID and UNCITRAL, are structurally biased towards developed states and business corporations. They argue that the awards of these institutions regularly favor the commercial interests of powerful investing corporations over the development concerns of weaker states. ${ }^{42}$ Doubts about the impartiality of arbitrators, inconsistent arbitral awards, secrecy of the proceedings, and the absence of any appeal mechanism for reviewing arbitration awards contribute to further skepticism about dispute settlement under the regime. ${ }^{43}$

Such concerns and criticisms have given rise to resistance to the investor-state regime from a number of sources. A variety of civil society groups, such as human rights, labor, and environmental organizations, are pressuring their governments to step in and reassert their policy and legislative autonomy. Governments are responding in a number of interesting ways that signal important transformations in statehood. A significant development is the appeal to international human rights to shore up these efforts to regain access to the policy and legislative levers that have been restrained by new constitutional governance under the investor-state regime.

\section{Human Rights, Statehood, AND ResistanCE to the INVESTOR- STATE REGIME}

The ability of governments or civil society groups to challenge the investor-state regime by appealing to international human rights is challenged by many of the same problems associated with more general

41. Choudhury, supra note 17 , at $778-79$.

42. See Gus Van Harten, Investment Treaty Arbitration, Procedural Fairness, and the Rule of Law, in INTERNATIONAL INVESTMENT LAW AND COMPARATIVE PUBLIC LAW 642-43 (Stephan W. Schill ed., 2010) (focusing on institutional and procedural aspects of these institutional systems that raise suspicions of bias); see also Julien Fouret, The World Bank and ICSID: Family or Incestuous Ties?, 4 INT'L ORG. L. REV. 121, 123 (2007) (arguing that the financial aspect of the activity of the World Bank provided an incentive to invest in developing States, but the same States appear in ICSID tribunals, the child institution of the World Bank).

43. See Van Harten, supra note 42. 
efforts to hold transnational corporations accountable under international law for human rights. As Rachel Anderson argues, "[foreign] direct investment policy-making continues to rely heavily on neoclassical economic theory," which advocates minimal government intervention to allow the market to generate public prosperity. ${ }^{44}$ She notes further that the bilateral investment treaty is "generally structured to protect transnational corporations from acts of expropriation ... without adequate compensation ... [and] tend[s] to omit societal stakeholders, such as individuals and communities affected by businesses owned, operated, or managed by transnational corporations." 45 Indeed, the distinction between private international law (conceived of as relating to commercial matters, governed by the principle of party autonomy) and public international law (regarded as relating to matters of a public nature between states) has obstructed the development of an understanding of overlap or nexus between the private and public spheres and of the political nature of many private matters. ${ }^{46}$

The regulatory preference in the investment regime has been on voluntarism and the promotion of soft, nonbinding corporate social responsibilities (CSRs). ${ }^{47}$ However, the voluntary nature of rules seeking to hold corporations accountable, such as the Guidelines on Multinational Corporations (MNCs) and the UNGPs issued by the Organisation for Economic Co-operation and Development, poses real problems of enforceability. Indeed, the UNGPs make clear the distinction between the "responsibilities" that businesses have for upholding human rights and the "legal duties" of states to protect the rights of foreign investors. ${ }^{48}$ This distinction between the responsibilities

44. Rachel J. Anderson, Toward Global Corporate Citizenship: Reframing Foreign Direct Investment Law, 18 MICH. ST. U. COLL. L. J. INT'L L. 1, 2 (2009).

45. Id. at 4.

46. See A. Claire Cutler, Artifice, Ideology, and Paradox: The Public/Private in International Law, 4 REV. INT'L POL. ECON. 261, 274-76 (1997) ("[T]he [public/private] distinction still operates conceptually and ideologically, serving to conceal the foundational role played by private international law in legitimizing processes of privatization and globalization.").

47. For an insightful discussion of CSR, see generally Radu Mares, De-centering Human Rights from the International Order of States: The Alignment and Interaction of Transnational Policy Channels, 23 IND. J. GLOBAL LEGAL STUd. 171 (2016).

48. The second guiding principle articulates the "expectation that all business enterprises . . . respect human rights throughout their operations[,]" Special Representative of the Secretary-General, Guiding Principles on Business and Human Rights: Implementing the United Nations 'Protect, Respect and Remedy" Framework: Report of the Special Representative of the Secretary-General on the Issue of Human Rights and Transnational Corporations and Other Business Enterprises, 7, 17th Sess. Hum. Rts. Council, U.N. Doc. A/HRC/17/31 (March 21, 2011), while the commentary attached 
of corporations and the legal duties of states has its origin in public international law. As mentioned earlier, the doctrine of international legal personality traditionally limits legal subjectivity to states and to state representatives, thus blocking corporations from holding rights or duties under international law. Only states or their delegates are competent to enter into international treaties and to hold legal rights and duties thereunder, unless legal rights and duties are found elsewhere, as in the case of international human rights law. In the past, any protections to be accorded to foreign investors depended on the principles of state responsibility to aliens and their property and on the political discretion of a home state to advance the interests of investing nationals. Prior to the development of the investor-state regime and the legal capacity for a corporation to directly sue a host state, the investing corporation really had no direct rights, but only those that its national state might or might not enforce on its behalf. In terms of the legal duties of foreign investing corporations, the investor-state regime is basically silent. Recall that IIAs and BITs articulate the rights of investing states, but not the rights of host states. The investor-state regime is designed to protect the foreign investor and investment. Any legal duties of transnational corporations to protect human rights must therefore be found outside the investor-state regime. This one-sided nature of the investor-state regime has prompted some to conclude that it distorts the balance between public and private authority:

\begin{abstract}
[T] he one-sided nature of the dispute settlement system, in which only private investors may initiate a claim and only states must pay damages, privileges private property and contract rights over the public interest. It creates a system of third-party beneficiaries, making the regime more rigid. It promotes private rights and relegates states to defensive status. BITs thus collapse the public/private binary and shift the boundary between the public good and private interests by privatizing part of the public. This re-conceptualization limits the influence of "public" concepts traditionally considered part of the state such as human rights, the environment, and democracy. ${ }^{49}$
\end{abstract}

provides that the "responsibility of business enterprises to respect human rights is distinct from issues of legal liability and enforcement, which remain defined largely by national law provisions in relevant jurisdiction." Id. at 13-14.

49. Asha Kaushal, Revisiting History: How the Past Matters for the Present Backlash Against the Foreign Investment Regime, 50 HARV. INT'L L.J. 491, 519 (2009). 
The investor-state regime has thus made a profound impact on statehood by according significant rights to foreign investors vis-à-vis states, but has simultaneously limited the ability of host states to regulate their domestic societies in ways that might impair foreign investment. Paradoxically, foreign investors have utilized these one-way agreements to develop and expand the rights provided them under guaranteed standards of "fair and equitable treatment," "full protection and security," "national treatment," "most-favored-nation treatment," and "treatment in accordance with international law." While there are several ways that human rights have entered into the investor-state regime, ${ }^{50}$ an interesting dialectic is emerging in the impact that international human rights are having on the investment regime and statehood. In some cases international human rights are being raised by foreign investors in defense of their property and market-based rights under the investment regime. In such cases, human rights are used to shore up and even expand the private property rights protected by investment agreements. However, in other cases, as in a Polanyian countermovement, human rights are used to contest the foundations of the investment regime and to reassert statehood and the protection of rights other than market-based rights.

By far the most active reliance on human rights doctrines has been that of foreign investors advancing their right to standards of treatment provided for in the investment agreement or BIT. Indeed, corporations have greatly expanded the scope of corporate rights in the development of arbitral decisions clarifying the nature and scope of treaty-based rights, such as "fair and equitable treatment," "full protection and security," "national treatment," "most-favored-nation treatment," and "treatment in accordance with international law". 51 In many cases foreign investors have invoked human rights protections provided in a number of regional and international human rights treaties, thereby expanding the investment regime. Specifically, the protections afforded by the European Convention on Human Rights in cases taken before the European Court of Human Rights have been a significant vehicle for investor claims, in addition to claims being made before arbitrations

50. Briefly, human rights might be raised by foreign investors in protection of rights they have under the investment agreement in a claim against a host state; they may be relied upon by the host state in defense of a claim; or they may be raised by a nondisputing party (NDP). Human rights may also be raised by the Tribunal and utilized by arbitrators as construction aids in interpreting the provisions of a BIT. Finally human rights might be expressly incorporated into a BIT. See Cutler, supra note 22, at 25-28.

51. See generally NeWCOMBE \& PARADELL, supra note 20 (examining the origins and evolution of investment treaty law and practice, the law applicable to investment treaty disputes, and substantive investment legal issues, including standards of treatment and exceptions and defenses to treaty obligations). 
under the relevant BITs. ${ }^{52}$ However, of more interest to this discussion are the instances where human rights have been relied on to contest the operations of the investor-state regime.

In a number of cases, host states have raised human rights in defense of claims that they have breached an investment agreement. Many of these cases concern disputed public utility investments, often prompting the host state's defense that it was protecting a variety of human rights. Numerous such cases resulted from the Argentinian financial crisis and contentious privatization initiatives for gas, water, and sewage services. ${ }^{53}$ In a review of these cases, Reiner and Schreuer conclude that the host state human rights claims "have been met with little enthusiasm" 54; the awards "seem to indicate the tribunals' reluctance to take up matters concerning human rights, preferring to dismiss the issues raised on a procedural basis rather than dealing with the substantive arguments themselves." 55 In CMS Gas $v$. Argentina, the tribunal found that there were no fundamental human rights affected, rejecting the Argentinian claim that emergency measures taken (limitations on deposits and abolishment of dollarization) were necessary to secure Argentinian citizens' fundamental right to be protected from the vicissitudes of the market in a crisis. ${ }^{56}$ In a close reading of the tribunal's reasoning, David Schneiderman caustically observes that this award "illustrates how economic globalization's legal order is intended to check national legislative action in regard to markets, despite the fact that national states continue to provide critical legitimating supports to the global project." 57

52. See, e.g., Luke Eric Peterson, Human Rights and Bilateral Investment Treaties: MapPing the ROLE OF HUMAN RightS LAW Within INVESTOR-STate ARBITRATION 23 n.44 (2009) (concerning the Russian oil company, Yukos, and claims against Ukrainian government made by Limited Liability Company AMTO).

53. See, e.g., CMS Gas Transmission Co. v. Republic of Argentina, ICSID Case No. ARB/01/08, Award, ๆ 121 (May 12, 2005); Suez, Sociedad General de Aguas de Barcelona S.A. and Vivendi Universal, S.A. v. Argentine Republic, ICSID Case No. ARB/03/19, Decision on Liability, II 1-2 (July 30, 2010); Suez, Sociedad General de Aguas de Barcelona S.A. v. Argentine Republic, ICSID Case No. ARB/03/19, Decision on Liability, If 1-2 (July 30, 2010).

54. Clara Reiner \& Christoph Schreuer, Human Rights and International Investment Arbitration, in HUMAN RIGHTS IN INTERNATIONAL INVESTMENT LAW AND ARBITRATION 82, 90 (Pierre-Marie Dupuy et al. eds., 2009).

55. Id.

56. See CMS Gas, ICSID Case No. ARB/01/08, ๆ 121 ("[T] he Tribunal does not find any such collision. . . [T] [There is no question of affecting fundamental human rights when considering the issues disputed by the parties.").

57. David Schneiderman, Resisting Economic Globalization: Critical theory AND INTERNATIONAL INVESTMENT LLAW 45 (2013). 
Other cases involving water and sewage privatization initiatives were brought against Argentina. In each case, the state was engaged in water-sector privatization schemes and the granting of concessions to foreign water corporations. In Suez, Sociedad General de Aguas de Barcelona S.A. and Vivendi Universal S.A v. Argentine Republic, an ICSID arbitration, investors were claiming breach of a number of BITs that Argentina had entered into with their home countries. ${ }^{58}$ The case involved a thirty-year contract to manage a water and sewage concession. ${ }^{59}$ Over the course of the relationship, a number of disputes arose and, with the intensification of the Argentine financial crisis, the parties were at odds over the tariff-rates charged to consumers. The investors wanted to modify the rates under the economic-equilibrium clause in the concession agreement. However, Argentina resisted. The human right to water was invoked by Argentina as one argument in its defense of necessity to its termination of the water concession, supported by amici curiae submissions filed by five nongovernmental organizations (NGOs) (this case is the first under ICSID in which such submissions were accepted despite the objections of one of the parties). The tribunal emphasized the "defense's exceptional nature and the strict conditions surrounding its application."60 It rejected Argentina's defense 'because Argentina's measures in violation of the BITs were not the only means to satisfy its essential interests and because Argentina itself contributed to the emergency situation that it was facing in 20012003."61

The tribunal's evaluation of the human-right-to-water argument is relatively brief and occurs within its consideration of the third element of the defense of necessity, that the treaty obligation does not exclude the necessity defense, an element Argentina was held to have satisfied. Nevertheless, the tribunal emphasized that Argentina's obligations to uphold human rights were additional to its obligation to uphold their investment treaty commitments and did not relieve it from those obligations:

Argentina and the amicus curiae submissions received by the Tribunal suggest that Argentina's human rights obligations to assure its population the right to water somehow trumps its obligations under the BITs and that the existence of the human right to water also implicitly

58. See Suez, Sociedad General de Aguas de Barcelona S.A., ICSID Case No. $\mathrm{ARB} / 03 / 19$, ๆ 1-2.

59. Id. I 34 .

60. Id. \ 258.

61. Id. ๆ 265. 
gives Argentina the authority to take actions in disregard of its BIT obligations. The Tribunal does not find a basis for such a conclusion either in the BITs or international law. Argentina is subject to both international obligations, i.e. human rights and treaty obligations, and must respect both of them equally. Under the circumstances of these cases, Argentina's human rights obligations and its investment treaty obligations are not inconsistent, contradictory, or mutually exclusive. Thus, as discussed above, Argentina could have respected both types of obligations. ${ }^{62}$

Impregilo S.p.A. v. Argentine Republic involved a factual background similar to the Suez case. ${ }^{63}$ Here, the dispute was over Argentina's refusal to permit price increases in the context of currency devaluation brought about by the Argentine financial crisis and the state's eventual transfer of the water and sewage service back to a state-sponsored company. As in the Suez case, Argentina invoked the defense of necessity based in part on its obligation to fulfill the human right to water. The human right to water was only indirectly addressed in the majority's decision. The tribunal held that the state's obligation to provide water was encompassed by the definition of an "essential interest," which a defendant must prove has been imperiled in claiming the defense of necessity:

[T] he term "essential interest" can encompass not only the existence and independence of a State itself, but also other subsidiary but nonetheless "essential" interests, such as the preservation of the State's broader social, economic and environmental stability, and its ability to provide for the fundamental needs of its population. It follows that, in addition to Argentina's overall stability, the need to provide the population with water and sewage facilities represented an "essential interest" which, in regard to thousands of people, was to be served by AGBA's concession and which would allegedly be "imperiled" for them but for the acts of the Argentine authorities. ${ }^{64}$

62. Id. ๆ 262.

63. Impregilo S.p.A. v. Argentine Republic, ICSID Case No. ARB/07/17, Award, ๆๆ 195231 (June 21, 2011).

64. Id. ๆ 346 (footnote omitted). 
Although the tribunal found that there was a grave and imminent peril to the essential interest of Argentina's economic stability, it ultimately held that Argentina contributed to the crisis and thus was not successful in invoking the necessity defense, with no further reference to the human right to water.

Schneiderman argues that, in the Suez case,

[i]t simply was beyond the capacity of the tribunal to acknowledge even the possibility of reversing the investment law regime's order of priority.... One gets the sense that these tribunals believed that Argentina not only contributed to its own demise, it actually benefited from its aggressive embrace of market disciplines. ${ }^{65}$

Others have suggested that these cases reveal "structural differences" between the orientations of public international law and international investment law that have biased investment tribunals toward enforcing the contractual rules agreed upon by host states and investors over the enforcement of conflicting obligations such as human rights. ${ }^{66}$

There is much evidence suggesting that the developing arbitral norm is restraint in expanding the defensive reliance on human rights in investment relations. In Glamis Gold Ltd. v. United States of America, Glamis Gold Ltd., a publicly held Canadian corporation engaged in the mining of precious metals, submitted a NAFTA claim to arbitration under the UNCITRAL Arbitration Rules on behalf of its enterprises Glamis Gold, Inc. and Glamis Imperial Corporation for alleged injuries relating to a proposed gold mine in Imperial County, California. ${ }^{67}$ Glamis claimed that certain federal and state measures with respect to open-pit mining operations resulted in the expropriation of its investments and denied its investments the minimum standard of treatment under international law. The California measures included regulations requiring backfilling and grading for mining operations in the vicinity of Native American sacred sites. Glamis claimed damages of not less than $\$ 50$ million. The tribunal refused the award, dismissing Glamis's claim in its entirety and ordering Glamis to pay two-thirds of the arbitration costs in the case. ${ }^{68}$

65. SCHNEIDERMAN, supra note 57, at 49.

66. Moshe Hirsch, Interactions Between Investment and Non-Investment Obligations, in THE OXFORD HANDBOOK OF INTERNATIONAL INVESTMENT LAW 154, 179 (Peter Muchlinski et al. eds., 2008).

67. Glamis Gold, Ltd. v. United States, ICSID, Award, I 10-11 (June 8, 2009).

68. Id. ๆ 26. 
In Glamis Gold, the Quechan Indian Nation submitted an amicus curiae brief arguing that the NAFTA provisions should be interpreted in a manner consistent with U.S. obligations in treaty and customary law to protect indigenous peoples' land and resources. In general, the award contains many references to the Quechan Nation, particularly during the course of the factual overview, which details their involvement in various environmental and cultural impact assessments. The backfilling and grading requirements were imposed by the state as an attempt to protect adjacent Quechan sacred sites without imposing an outright ban on mining, or even more excessive costs on Glamis. The tribunal held that the economic impact of the state's measures were not sufficient to effect expropriation of Glamis's investment. ${ }^{69}$ The respondent did not choose to incorporate into its defense the arguments made in the amicus curiae brief of the Quechan Indian Nation. As a result, there is no reference to human rights claims or their incorporation into the concept of fair and equitable treatment, either in the respondents' arguments or in the tribunal's analysis. While the tribunal ultimately dismissed the claim by the investor, it briefly considered harms relating to the proposed mining project and concluded that the measures adopted by the host state were not arbitrary. In the following comments the tribunal clearly indicated that it was not taking into account the human rights and environmental claims raised:

The Tribunal is aware that the decision in this proceeding has been awaited by private and public entities concerned with environmental regulation, the interests of indigenous peoples, and the tension sometimes seen between private rights in property and the need of the State to regulate the use of property. . . . However, given the Tribunal's holdings, the Tribunal is not required to decide many of the most controversial issues raised in this proceeding. The Tribunal observes that a few awards have made statements not required by the case before it. The Tribunal does not agree with this tendency; it believes that its case-specific mandate and the respect demanded for the difficult task faced squarely by some future tribunal instead argues for it to confine its decision to the issues presented. ${ }^{70}$

69. Id. ๆ 17.

70. Id. $\Upsilon 8$. 
As in the Glamis case, it appears that human rights may also arise in an investment relationship through the agency of nonparties. In fact, the applications of civil society, environmental, and human rights groups to participate in investor-state arbitration proceedings as amici curiae have proliferated and have been a source of significant development in enhancing the public and participatory dimensions of the regime. The initial response of tribunals to broadening participation to nonparties was not positive. In Aguas del Tunari v. Bolivia, petitioners in ICSID proceedings argued for amici curiae participation on the basis of the right to a fair trial under the International Covenant on Civil and Political Rights. ${ }^{71}$ The case involved a claim by Bechtel, an American company operating the water and sewage system for Cochabamba, Bolivia, through its subsidiary, Aguas del Tunari, under a forty-year lease, as part of a World Bank-inspired privatization scheme. Within weeks of taking over the operation of the water system, the rates were increased by so much that families living on the minimum wage were being billed up to 25 percent of their monthly income. The rate increases resulted in massive protests, the declaration of martial law, and many injuries. ${ }^{72}$ Protests continued, and in 2000 Bechtel abandoned the project and filed a claim for lost profits. The claim was filed with ICSID under the Dutch-Bolivian BIT and, despite Bolivia's opposition, the tribunal ruled that it had jurisdiction over the dispute through Bechtel's subsidiary in the Netherlands. ${ }^{73}$ The case remained in arbitration for some years until Bechtel, responding to pressure to drop the case, settled the $\$ 50$ million claim for a symbolic thirty cents. ${ }^{74}$ Several NGOs filed petitions for amici curiae participation and argued that the people affected by the soaring water prices were being denied the human right to water. ${ }^{75}$ The petitions to submit amicus briefs were rejected on the grounds that the tribunal lacked the authority to admit the briefs of nonparties in the absence of the parties' consent, but left the door open for such submissions in other cases. ${ }^{76}$

71. See Aguas del Tunari, S.A. v. Republic of Bol., ICSID Case No. ARB/02/3, Petition to Participate of La Coordinadora para la Defensa del Agua y Vida et al., I $\uparrow$ 47-48 (Aug. 29, 2002); Aguas del Tunari, S.A. v. Republic of Bol., ICSID Case No. ARB/02/3, Letter from President of Tribunal Responding to Petition (Jan. 29, 2003).

72. Aguas, ICSID Case No. ARB/02/3, Petition to Participate at $\| 1$.

73. Aguas del Tunari, S.A. v. Republic of Bol., ICSID Case No. ARB/02/3, Decision on Respondent's Objections to Jurisdiction, at 79 (Oct. 21, 2005).

74. Elena Blanco \& JoHn RazZaque, Globalization and Natural REsource Law: Challenges, Key IsSues AND PERSPECTIVES 261 (2011).

75. Amanda Norris and Katina Metzidakis, Public Protests, Private Contracts: Confidentiality in ICSID Arbitration and the Cochabamba Water War, 15 HARV. NEGOT. L. REV. 31, 50-51 (2010).

76. Id. at 53 . 
The case of Methanex $v$. United States was the first investment arbitration by a NAFTA tribunal under UNCITRAL rules that allowed NGOs to submit written briefs as amici curiae. ${ }^{77}$ Methanex Corporation is a Canadian company that claimed compensation for damages resulting from the ban imposed by California on the use of methyl tertbutyl ether, a fuel additive produced by the company. ${ }^{78}$ The International Institute for Sustainable Development, NGOs for a Better Environment, and the Earth Institute requested rights to submit briefs, to be granted observer status, and to receive documentary materials. The tribunal allowed the submission of briefs but not observer status or access to materials on the basis of confidentiality and privilege. ${ }^{79}$ It arrived at this decision after inviting comments from the parties and other NAFTA states on the amicus petition. Methanex and Mexico initially opposed the submission of briefs, while the United States and Canada supported the petition. The tribunal differentiated between the filing of an amicus submission and the adding of a party to the dispute, stressed the importance of the parties' consent, and adopted a statement on the participation of nondisputing parties provided by the NAFTA Free Trade Commission (FTC). ${ }^{80}$ Subsequently, two briefs were filed by the NGOs and were accepted by the parties. ${ }^{81}$

The FTC issued an interpretive note to the effect that Chapter 11 rules do not impose "a general duty of confidentiality or preclude the Parties from providing public access to documents" and that the parties "agree to make available to the public in a timely manner all documents submitted" subject to confidential material which is privileged or protected by law from disclosure. ${ }^{82}$ Subsequently, Canada and the United States issued statements in support of opening NAFTA hearings to the public using the appropriate technology (closed-circuit television, Internet webcasting) ${ }^{83}$ Mexico later adopted this position as well. ${ }^{84} \mathrm{It}$ is

77. See Methanex Corp. v. United States, UNCITRAL, Decision of the Tribunal on Petitions from Third Persons to Intervene as "Amici Curia," If 47 (Jan. 15, 2001) [hereinafter Methanex Amicus Curia].

78. Howard ManN, The Final Decision in Methanex v. United States: Some New WINE IN SOME NEW BOTTLES 2 (2005), available at http://www.iisd.org/pdf/2005/ commentary_methanex.pdf.

79. Methanex Amicus Curia, supra note 77, at $\ 47$.

80. See generally id. I 24-52 (discussing the tribunal's decision and reasoning).

81. MANN, supra note 78 , at 12 .

82. NAFTA Free Trade Comm'n, Notes of Interpretation of Certain Chapter 11 Provisions (July 31, 2001), available at http://www.sice.oas.org/tpd/nafta/Commission/ CH11understanding_e.asp.

83. Press Release, Office of the United States Representative, NAFTA Free Trade Commission Joint Statement - "A Decade of Achievement," NAFTA Joint Statement (Jul. 16, 2004), available at https://ustr.gov/archive/Document_Library/Press_Releases/2004/ 
important to note, however, that the scope of amicus participation remains very narrow and is regarded as performing a publicinformation function for the tribunals. It does not include participation as an observer or access to documents, unless the parties consent.

The Methanex case established a precedent that subsequently informed ICSID proceedings. ICSID Arbitration Rules were amended in 2006 to recognize the authority of a tribunal to admit amicus curiae briefs with the consent of the disputing parties. ${ }^{85}$ This was followed in the Suez case, mentioned above, as well as in a number of other cases arising out of the Argentinian financial crisis. UNCITRAL has similarly amended its procedures, adopting in 2014 Rules on Transparency in Treaty-Based Investor-State Arbitration, which provide for open, public hearings. ${ }^{86}$

A number of ICSID arbitrations have challenged provisions of South Africa's Black Economic Empowerment (BEE) policies that seek to redress historical racial inequalities, illustrating the intersection of investment obligations and human rights. 87 The new post-apartheid constitution provides for significant water, natural resource, and land reforms that many argued conflict with South African commitments under BITs. In 2006 European investors challenged South African legislation that provided for greater participation of blacks in the mining sector, mandated a 26 percent black ownership share, and changed private ownership over natural resources to government ownership and licensing arrangements. ${ }^{88}$ The legislation also provided for sustainable development and raised a number of environmental protection concerns. ${ }^{89}$ Italian investors who owned a granite company filed an ICSID claim under the Italy-South African BIT claiming that

July/NAFTA_Free_Trade_Commission_Joint_Statement_-_A_Decade_of_Achievement. html.

84. Id.

85. See generally Jason W. Yackee \& Jarrod Wong, The 2006 Procedural and Transparency-Related Amendments to the ICSID Arbitration Rules: Model Intentions, Moderate Proposals, and Modest Returns (Univ. of Wisconsin Legal Studies Research Paper No. 1151, Jan. 12, 2011), available at http://papers.ssrn.com/sol3/papers.cfm? abstract_id=1739174 (reviewing and evaluating the 2006 amendments to the ICSID Arbitration Rules).

86. Rules on Transparency, supra note 9 at art. 6.

87. See, e.g., Piero Foresti, Laura de Carli \& Others v. Republic of South Africa, ICSID Case No. ARB (AF)/07/01, Award, at If 64 (Aug. 4, 2010); see also Swiss Investor v. Republic of South Africa, UNCITRAL, Partial Award (July 2003).

88. Andrew Friedman, Flexible Arbitration for the Developing World: Piero Foresti and the Future of Bilateral Investment Treaties in the Global South, 7 INT'L L. \& MGMT. REV. 37, 40-41 (2010) (discussing South Africa's post-apartheid policies that lead to the extratribunal arbitral case of Piero Foresti v. Republic of South Africa).

89. Id. 
the legislation violates protections against discrimination and expropriation. ${ }^{90}$ Subsequently, Luxembourgish investors joined the claim and a number of NGOs applied to participate as amici curiae. Two South African NGOs, the Centre for Applied Legal Studies and the Legal Resource Centre, and two international NGOs, the Centre for International Environmental Law and the International Centre for the Legal Protection of Human Rights (and later the International Commission of Jurists), were successful in their petition to submit briefs and gain access to key documents. ${ }^{91}$ The NGOs argued that the BEE should be upheld in order to address historic discrimination, thus challenging investor rights with human rights. They also advanced significant environmental concerns. However, the case was settled and the claim discontinued..$^{92}$ It is noteworthy that this case precipitated South Africa's decision to terminate its European BITs. ${ }^{93}$ It showed the potentially dangerous conflict between public policy goals and international investment agreements providing for investor-state dispute settlement (ISDS). As a result, South Africa is reconsidering its adherence to ISDS (and has come forward with its "Promotion and Protection of Investment Bill" in 2012, expected to be updated in 2015, stating more precisely the national policy in addressing ISDS and BITs). While the substantive human rights and environmental protection issues were never decided, this case is regarded as significant in expanding innovative participation procedures governing non-disputing parties in ICSID. ${ }^{94}$

Notably, the advancement of human rights claims against corporations may be more successful outside the investor-state regime. In Sawhoyamaxa $v$. Paraguay, ${ }^{95}$ the indigenous community, Sawhoyamaxa, went before the Inter-American Court of Human Rights to argue that their right to land was violated by Paraguay's not returning to them lands held by a German investor. The right to land is

90. Piero Foresti, ICSID Case No. ARB(AF)/07/1, ๆ 54.

91. Id. I 25.

92. See id. ๆ 82.

93. Peter Leon et al., South Africa: South Africa Declines to Renew Bilateral Investment Treaties With European Union Member States, MONDAQ (Oct. 5, 2012), http://www.mondaq.com/x/199586/international trade investment/South (discussing the consequences and reactions to the BIT termination).

94. See Christina Knahr, The New Rules on Participation of Non-Disputing Parties in ICSID Arbitration: Blessing or Curse?, in Evolution IN TREATY LAW AND ARBITRATION 319, 328-30 (Chester Brown \& Kate Mills eds., 2011) (discussing dicta in Piero Foresti and the novelty of non-disputing party procedure).

95. Sawhoyamaxa v. Para., Merits, Reparations and Costs, Judgment, Inter-Am. Ct. H.R. (ser. C) No. 146 (Mar. 29, 2006). 
in fact recognized in Paraguay's constitution.96 The government defended by claiming that the expropriation of lands in favor of the Sawhoyamaxa would constitute a breach of the German-Paraguay BIT, but the court ruled that enforcement of a BIT does not justify noncompliance with human rights obligations. ${ }^{97}$ The court ruled that the government had breached the constitutional right to land. ${ }^{98}$ While it was years before the government sought to rectify the situation, this decision provides a good example of successful resistance to the investor-state regime and the subordination of private investment rights to public human rights.

This review illustrates how the legislative and policy autonomy of states to regulate human rights or environmental and health protections can be severely limited by the protections afforded foreign investors under the investor-state regime. While there has clearly been an expansion in the participation opportunities under NAFTA and ICSID arbitrations, nonparty participation remains significantly limited and the recognition of a nexus between investment obligations and human rights has been uneven. However, some states are responding to the one-sided nature of the investment agreement and are seeking to regain some legislative and policy autonomy. A number of international organizations are trying to recover the public dimension of private agreements, while the United Nations has identified this as a crucial determinant in sustainable development. ${ }^{99}$ To what extent are there possibilities for further transformations in statehood resulting from the development of the understanding of the nexus between human rights and the investor-state regime and for enhancing the democratic legitimacy of the regime through better balancing these often conflicting rights?

\section{ENHANCING THE LEGITIMACY OF THE INVESTOR-STATE REGIME}

The investor-state treaty regime constitutes a domain of international economic law that is a complex hybrid of private and public international law, grafting dispute resolution mechanisms developed for private international law onto public international law

96. See id. I 122; see also Special Rapporteur on the Rights of Indigenous Peoples, Comm'n on Human Rights, at 5-6, U.N. Doc. A/HRC/30/41 (Aug. 6, 2015) (by Victoria Tauli Corpuz).

97. Sawhoyamaxa, Inter-Am Ct. H.R. (ser. C) No. 146, ๆ 137.

98. Id.

99. See WORLD INVESTMENT REPORT, supra note 5, at 124 . 
treaties like IIAs and BITs. 100 This hybridity creates considerable ambiguity concerning the nature and function of investment arbitration proceedings and the appropriate interpretive doctrines and standards that are to be applied by arbitration tribunals. Indeed, the private-law origins of international commercial arbitration have given rise to concerns about the propriety and adequacy of employing private law concepts and practices informed by economic theories of law that fail to address the political dimension of the legal regimes, particularly when arbitral proceedings involve matters of public interest and concern. ${ }^{101}$

Private commercial and public international lawyers
have different perspectives on and different philosophies
about the role of law, the state, and the function of
dispute resolution. Also, their audiences and conceptual
approaches are often different. Whereas public
international lawyers embed international investment
law firmly in general international law and approach
the topic against that background, commercial
arbitration lawyers focus on dispute settlement and see
investment treaty arbitration as a subset of
international (commercial) arbitration. ${ }^{102}$

Arguably, we require the development of a more complex understanding of international investment regime in order to explore its intersection with human rights and other matters of public interest and law. For some, the field of international economic law, of which the investor-state regime forms part, requires a new socio-legal approach that is capable of integrating both the contexts and subtexts in which legal texts operate, "sometimes for the objective purpose of achieving clarity, sometimes with a view to changing them." 103 Others have called for greater pluralism in the "mapping" of international economic law to account for the substantive expansion of the field, the proliferation of

100. See Zachary Douglas, The Hybrid Foundations of Investment Treaty Arbitration, 74 BRIT. Y.B. INT'L L. 151, 153-58 (2003).

101. See William W. Burke-White \& Andreas von Staden, Private Litigation in a Public Law Sphere: The Standard of Review in Investor-State Arbitrations, 35 YALE J. INT'L L. 283, 285-86 (2010) ("[S]trict standards of review employed by many arbitral tribunals may be inappropriate with respect to many issues raised in modern investor-state arbitrations that are, at heart, public law questions.").

102. Stephan W. Schill, W(h)ither Fragmentation? On the Literature and Sociology of International Investment Law, 22 EUR. J. INT'L L. 875, 888 (2011).

103. Amanda Perry-Kessaris, What Does it Mean to Take a Socio-Legal Approach to International Economic Law?, in SOCIO-LEGAL APPROACHES TO INTERNATIONAL ECONOMIC LAW: TEXT, CONTEXT, SubTEXT 3, 15 (Amanda Perry-Kessaris ed., 2013). 
diverse actors involved, and multiple sites of international economic governance. ${ }^{104}$ I have made the case for the need for a critical political economy of international economic law that revisits distinctions between economics and politics and between public and private spheres. ${ }^{105}$ Critical political economy puts the distributional question of "who gets what" from private regimes of accumulation at the forefront of analysis. 106 Similarly, David Schneiderman calls for a critical politicaleconomic understanding of legal pluralist accounts of the investor-state regime that obscure the "ideological tilt" of the regime in favor of powerful capital-exporting states and that impose disciplines that lock host states into restrictions on their legislative and policy autonomy, severely restraining their political choices and democratic potential. 107 The investor-state regime operates through legal agreements, rules, and institutions that advance the protection of investor interests as the raison d'être of the regime, but does this have to be the case?

We have seen an expansion of participation rules in NAFTA, the WTO, ICSID, and UNCITRAL occurring in response to intense mobilization by civil society groups, human rights activists, environmentalists, and arbitration lawyers for increased public participation in the investor-state regime. These developments have enhanced the legitimacy of the investor-state regime considerably. But to what extent could human rights obligations be written right into the text of IIAs and BITs so as to form part of the investor-state legal relationship?

John Ruggie, the former Special Representative of the United Nations Secretary General on Business and Human Rights, adopted the position in the Guiding Principles that important "governance gaps" may be filled by express incorporation of obligations and rights into investment agreement:

States should maintain adequate domestic policy space to meet their human rights obligations when pursuing

104. See, e.g., Celine Tan, Navigating New Landscapes: Socio-Legal Mapping of Plurality and Power in International Economic Law, in Socio-LeGal APPROACHES TO InTERnational ECONOMIC LaW: TeXt, Context, Subtext 19, 19 (Amanda Perry-Kessaris ed., 2013).

105. A. Claire Cutler, Toward a Radical Political Economy Critique of Transnational Economic Law, in INTERNATIONAL LAW ON THE LEFT: RE-EXAMINING MARXIST LEGACIES 199, 200 (Susan Marks ed., 2008).

106. See generally id.

107. See David Schneiderman, Power and Production in Global Legal Pluralism: An International Political Economy Approach, in SOCIO-LEGAL APPROACHES TO International Economic Law: Text, Context, SubText 98, 108 (Amanda Perry. Kessaris ed., 2013). 
business-related policy objectives with other States or business enterprises, for instance through investment treaties or contracts [...] Economic agreements concluded by States, either with other States or with business enterprises-such as bilateral investment treaties, free-trade agreements or contracts for investment projects-create economic opportunities for States. But they can also affect the domestic policy space of Governments. For example, the terms of international investment agreements may constrain States from fully implementing new human rights legislation, or put them at risk of binding arbitration if they do so. Therefore, States should ensure that they retain adequate policy and regulatory ability to protect human rights under the terms of such agreements, while providing the necessary investor protection. ${ }^{108}$

There is some evidence that investment agreements are being conceptualized in this way. The International Institute for Sustainable Development (IISD), which is a charitable organization registered in Canada and financed almost completely by the Canadian government, made the first express link between the foreign investment relationship and sustainable development.109 It also developed the first model agreement that attempts to incorporate a variety of previously regarded "non-treaty" obligations into the investment treaty. ${ }^{110}$ The IISD Model International Investment Agreement states that its objective is "to promote foreign investment that supports sustainable development, in particular in developing and least-developed countries."111 It also provides for expropriation with compensation for public purposes, ${ }^{112}$ and articulates the obligations of both the investing corporation and the host state to uphold environmental, human, and labor rights. ${ }^{113}$

While the International Chamber of Commerce opposes the inclusion of labor or environmental standards into BITs, ${ }^{114}$ and very few

108. Special Representative of the Secretary-General, Guiding Principles on Business and Human Rights: Implementing the United Nations "Protect, Respect and Remedy" Framework, U.N. Doc. A/HRC/17/31, at 11 (Mar. 21, 2011) (by John Ruggie).

109. See Howard MANN ET AL., IISD MODEL INTERnational AgReEMENT on INVESTMENT FOR SUSTAINABLE DEVELOPMENT ii, $\mathbf{v}$ (2005), available at https://www.iisd.org/pdf/2005/investment_model_int_agreement.pdf.

110. Id. at iii.

111. Id. art. 1.

112. Id. art. 8.

113. Id. art. 21.

114. Van Harten, supra note 39, at 614. 
BITs mention human rights (save perhaps in general terms in the preamble, as does the Dutch Model BIT), ${ }^{115}$ some model BITs are moving in this direction. Canada developed a new model Foreign Investment Protection Agreement (FIPA), the Canadian equivalent of a BIT. ${ }^{116}$ The model FIPA embodies changes resulting from controversial experiences arbitrating under NAFTA's Chapter 11 investor-state provision. ${ }^{117}$ Controversy over Chapter 11 arbitrations stemmed from the criticisms advanced by environmental and civil society groups that investment commitments under NAFTA negatively impact public policy in a number of areas and inhibit sustainable development. Concerns about the secrecy of the arbitral proceedings and lack of public access to information about investment disputes motivated a review of NAFTA arbitrations by the NAFTA Free Trade Commission, which issued guidelines on the participation of nondisputing parties. ${ }^{118}$ As a result, Canada and the United States agreed to open NAFTA arbitrations to the public and have recently made the draft negotiating texts of NAFTA arbitrations publicly available. The new model treaty addresses many of the concerns expressed. The model FIPA refers to sustainable development in the preamble and contains a GATT-like general exception that applies to all the obligations in the model treaty. ${ }^{119}$ This exception covers measures adopted for the protection of human animal or plant life or health and conservation purposes. The model FIPA also provides for public access to all documents and public arbitral hearings. ${ }^{120}$ In addition, it provides a procedure for nondisputing parties to file written submissions. ${ }^{121}$ The U.S. model BIT goes further and addresses the relationship between investment and labor rights and

115. See Commentaries on Selected Model Investment Treaties 549 (Chester Brown, ed., 2013).

116. See generally LuKe ERIC Peterson, Evaluating Canada's 2004 Model Foreign INVESTMENT PRotection AgreEment IN Light of CIVIL Society CONCERNS (2006), available at $\mathrm{http}: / / \mathrm{www} . c c i c . c a /$ files/en/what_we_do/trade_2006-06_foreign_investment_ memo_e.pdf (evaluating Canada's 2004 FIPA).

117. Id. at 2-3.

118. Id.

119. See Agreement Between Canada and For the Promotion and Protection of Investments, art. 10, available at http://www.italaw.com/documents/Canadian2004-FIPAmodel-en.pdf [hereinafter Canada's Model FIPA].

120. However, the recently negotiated Canada-China FIPA departs from this practice and does not provide for public access to documents and hearings in arbitration proceedings as a general rule. See Catherine Walsh \& Michael G. Woods, The CanadaChina Foreign Investment Promotion and Protection Agreement: Part II: Investor-State Dispute Settlement Provisions, Woons LAFoRTUNE LLP (July 8, 2014), http://www.wltradelaw.com/the-canada-china-foreign-investment-promotion-and-protection-agreementpart-ii-investor-state-dispute-settlement-provisions.

121. See Canada's Model FIPA, supra note 119, art. 33. 
expands the scope for state policy autonomy. The Australia-U.S. Free Trade Agreement does not provide for investor-state arbitration, and in 2011 Australia announced that it would no longer include such provisions in its trade agreements due to concerns about sovereignty. ${ }^{122}$

\section{CONCLUSION}

These developments indicate a rethinking of assumptions concerning the nature and role of international commercial law and practice and the boundaries of statehood. They also suggest the emergence of a more critical understanding of the separations between economics and politics and the private and public spheres that have obscured the significant distributional impact of investment agreements. There is decidedly more understanding today of the "political" nature of the investor-state regime and its centrality as a mechanism of global governance than in the past. This analysis reveals that transformations in statehood have occurred in the past and continue to take place under the investor-state regime. The first transformation that served to narrowly circumscribe the policy and legislative autonomy of states occasioned significant resistance and a countermovement. A further transformation is underway amongst many states seeking to regain lost or compromised autonomy. This is most heartening in light of the typically glacial pace of international law. These transformations also signal the important development of the nexus between private corporate rights and international human rights. However, there is much more room left for the investor-state regime to accommodate human rights concerns, which in my view might be advanced through activism at multiple levels.

122. Austl. Gov't Dep't of Foreign AfFairs \& Trade, GILLARd Government Trade Policy Statement: Trading OUR Way to MORE JobS aNd Prosperity 14 (Apr. 2011), available at http://blogs.usyd.edu. au/japaneselaw/2011_Gillard\%20Govt\%20Trade\%20 Policy\%20Statement.pdf. 